\title{
VARIASI GEJALA COVID-19 YANG DIALAMI PERAWAT MURNI TEGUH MEMORIAL HOSPITAL
}

\author{
Seriga Banjarnahor \\ Program Studi Ilmu Keperawatan, STIKes Murni Teguh \\ E-mail : serigabanjarnahor@yahoo.com
}

\begin{abstract}
COVID-19 is a virus that threatens health throughout the world. The spread of this virus is very fast and people who are exposed to COVID-19 generally bring out symptoms that have not yet to be fully explained. This study aims to know the symptoms of COVID-19 experienced by nurses at Murni Teguh Memorial Hospital who were confirmed positive COVID-19. This type of research is a quantitative research with a descriptive design. The number of respondents in the study was 31 nurses, which were obtained by using the total sampling method. The results of this study indicate that the symptoms experienced by nurses are vary, ranging from asymptomatic $(22,4 \%)$ and the dominant symptoms felt by nurses such as loss of smell $(64,5 \%)$, fever $(54,8 \%)$, and cough $(51,6 \%)$.
\end{abstract}

Keyword : COVID-19, Symptoms, Nurse

\begin{abstract}
Abstrak
COVID-19 merupakan virus yang mengancam kesehatan sampai saat ini di seluruh dunia. Penyebaran virus ini sangat cepat dan orang yang terpapar COVID-19 umumnya menimbulkan suatu gejala yang hingga saat ini belum sepenuhnya dapat dijelaskan. Penelitian ini bertujuan untuk mengetahui gejala COVID-19 yang di alami perawat Murni Teguh Memorial Hospital yang terkonfirmasi positif COVID-19. Jenis penelitian yang digunakan adalah penelitian kuantatif dengan desain deskriptif. Responden penelitian berjumlah 31 perawat, yang diperoleh dengan metode total sampling. Hasil penelitian ini menunjukkan gejala yang di alami perawat bervariasi, mulai dari asimptomatik $(22,4 \%)$, dan gejala dominan yang dirasakan perawat seperti hilangnya indera penciuman $(64,5 \%)$, demam $(54,8 \%)$, dan batuk $(51,6 \%)$.
\end{abstract}

Kata Kunci : COVID-19, Gejala, Perawat

\section{PENDAHULUAN}

Corona Virus Disease 2019 atau disebut dengan COVID-19, masih menjadi masalah kesehatan di dunia hingga saat ini. COVID-19 disebabkan oleh virus Severe Acute Respiratory Syndrome Coronavirus 2 (SARS-CoV-2) dan kasusnya pertama sekali terjadi pada bulan Desember 2019 di Kota Wuhan, China. Dalam waktu yang relatif singkat, virus ini menyebar ke berbagai daerah di China dan di berbagai Negara di dunia. Di Indonesia, kasus COVID-19 pertama sekali teridentifikasi pada tanggal 2 Maret 2020, saat ada dua orang terkonfirmasi positif COVID-19 yang di rawat di Rumah Sakit Penyakit Infeksi (RSPI) Sulianti Saroso
Kota Jakarta. Dalam waktu 8 hari setelah kasus ini terindentifikasi, yaitu pada tanggal 10 April 2020, COVID-19 telah menyebar ke berbagai daerah di Indonesia (CNN, 2020).

Tidak hanya di Indonesia, penyebaran COVID-19 semakin hari semakin meningkat di berbagai Negara di dunia. World Health Organization (2020) melaporkan bahwa kasus COVID-19 yang telah dikonfirmasi di dunia sampai tanggal 26 September 2020, yakni sebanyak 32, 1 juta kasus. Jumlah total pasien COVID-19 yang meninggal ada sebanyak 980 ribu kasus. Untuk regional Asia Tenggara, jumlah kasus terkonfirmasi, yakni 6,53 juta kasus. Jumlah kasus yang meninggal, yakni 
sebanyak 108 ribu kasus. Di Indonesia, jumlah kasus terkonfirmasi ada sebanyak 271.339 kasus. Untuk jumlah kasus yang sembuh ada sebanyak 199.403. Sementara itu, jumlah kasus meninggal ada sebanyak 10.308 (Kemenkes, 2020).

COVID-19 pada umumnya dapat menyebabkan gejala seperti demam, batuk, sakit tenggorokan, nafas pendek, kelelahan dan juga nyeri otot (Singhal, 2020). Beberapa gejala masih belum sepenuhnya dapat dijelaskan. Oleh karena itu, peneliti akan melakukan penelitian untuk dapat mengetahui gejala-gejala yang dialami oleh pasien COVID-19 khususnya pada tenaga kesehatan, yakni perawat.

\section{METODE PENELITIAN}

Jenis penelitian yang digunakan yaitu penelitian kuantitatif dengan desain deskriptif. Penelitian ini dilakukan pada bulan Juli sampai dengan Agustus 2020.

Sampel pada penelitian ini yaitu seluruh perawat Murni Teguh Memorial Hospital yang terkonfirmasi positif COVID19. Teknik pengambilan sampel adalah total sampling. Jumlah sampel pada penelitian ini, yaitu 31 orang.

Instrumen yang digunakan dalam penelitian ini, yaitu lembar kuesioner data demografi dan kuesioner gejala COVID-19. Kuesioner ini berbentuk pilihan berganda dengan pilihan jawaban berupa Ya dan Tidak.

\section{HASIL PENELITIAN}

\section{Karakteristik demografi responden}

Responden yang terlibat dalam penelitian ini, yakni perawat Murni Teguh Memorial Hospital yang terkonfirmasi positif COVID-19, yakni berjumlah 31 orang. Di ketahui bahwa sebagian besar perawat berada pada kelompok usia 26-35 tahun, yaitu sebanyak 15 orang $(48,4 \%)$. Mayoritas perawat berjenis kelamin perempuan, yakni sebanyak 27 orang $(87,1 \%)$. Mengenai riwayat penyakit dan penyakit komorbid, mayoritas responden tidak memiliki riwayat penyakit, yakni sebanyak 26 orang $(83,9 \%)$.
Berikut diuraikan karakteristik responden pada tabel 1.

\begin{tabular}{|c|c|c|c|}
\hline \multicolumn{2}{|c|}{$\begin{array}{l}\text { Tabel 1. Karakteristik } \\
\text { Responden }(n=31)\end{array}$} & \multicolumn{2}{|c|}{ Demografi } \\
\hline No. & Karakteristik & $\mathbf{F}$ & $\%$ \\
\hline \multirow[t]{5}{*}{1.} & Usia & & \\
\hline & 17-25 Tahun & 11 & 35,5 \\
\hline & 26-35 Tahun & 15 & 48,4 \\
\hline & 36-45 Tahun & 3 & 9,7 \\
\hline & 46-55 Tahun & 2 & 6,5 \\
\hline \multirow[t]{3}{*}{2.} & Jenis Kelamin & & \\
\hline & Perempuan & 27 & 87,1 \\
\hline & Laki-laki & 4 & 12,9 \\
\hline \multirow[t]{3}{*}{3.} & Riwayat Penyakit & & \\
\hline & Ada & 5 & 16,1 \\
\hline & Tidak ada & 26 & 83,9 \\
\hline \multirow[t]{6}{*}{4.} & Penyakit Komorbid & & \\
\hline & Tidak ada & 26 & 83,9 \\
\hline & Transient Ischemic Attack & 1 & 3,2 \\
\hline & Infeksi Saluran Kemih & 2 & 6,5 \\
\hline & Sinusitis & 1 & 3,2 \\
\hline & Diabetes Melitus & 1 & 3,2 \\
\hline
\end{tabular}

Analisa Univariat

Kuesioner gejala COVID-19 diberikan kepada 31 perawat Murni Teguh Memorial Hospital yang terkonfirmasi COVID-19. Hasil Penyebaran kuesioner mengenai gejala COVID-19 menunjukkan bahwa sebanyak sebanyak 17 orang $(54,8 \%)$ mengalami demam, sebanyak 16 orang $(51,6 \%)$ mengalami batuk, sebanyak 20 orang $(64,5 \%)$ mengalami hilangnya indera penciuman, sebanyak 30 orang $(96,8 \%)$ tidak mengalami sesak nafas, sebanyak 29 orang $(93,5 \%)$ tidak mengalami sakit tenggorokan, sebanyak 26 orang $(83,9 \%)$ tidak mengalami sakit kepala, sebanyak 30 orang $(96,8 \%)$ tidak mengalami mual, sebanyak 30 orang $(96,8 \%)$ tidak mengalami muntah, sebanyak 30 orang $(96,8 \%)$ tidak mengalami diare, sebanyak 30 orang $(96,8 \%)$ tidak mengalami pilek, sebanyak 31 orang (100\%) tidak mengalami ruam kulit dan konjungtivitis, dan sebanyak 30 orang $(96,8 \%)$ tidak ada masalah dengan nafsu makan. Dari keseluruhan responden, terdapat 7 orang perawat yang tidak memiliki keluhan atau gejala namun terkonfirmasi COVID-19. Distribusi frekuensi dan persentase gejala 
COVID-19 dalam dilihat lebih rinci pada tabel 2.

Tabel 2. Distribusi Frekuensi dan Persentase Gejala COVID-19

\begin{tabular}{|c|c|c|c|}
\hline No. & Karakteristik & $\mathbf{F}$ & $\%$ \\
\hline \multirow[t]{3}{*}{1.} & Demam & & \\
\hline & Ya & 17 & 54,8 \\
\hline & Tidak & 14 & 45,2 \\
\hline \multirow[t]{3}{*}{2.} & Batuk & & \\
\hline & Ya & 16 & 51,6 \\
\hline & Tidak & 15 & 48,4 \\
\hline \multirow[t]{4}{*}{3.} & Hilang Indera & & \\
\hline & Penciuman & & \\
\hline & Ya & 20 & 64,5 \\
\hline & Tidak & 11 & 35,5 \\
\hline \multirow[t]{3}{*}{4.} & Sesak Nafas & & \\
\hline & Tidak & 30 & 96,8 \\
\hline & Ya & 1 & 3,2 \\
\hline \multirow[t]{3}{*}{5.} & Sakit Tenggorokan & & \\
\hline & Tidak & 29 & 93,5 \\
\hline & Ya & 2 & 6,5 \\
\hline \multirow[t]{3}{*}{6.} & Sakit Kepala & & \\
\hline & Tidak & 26 & 83,9 \\
\hline & $\mathrm{Ya}$ & 5 & 16,1 \\
\hline \multirow[t]{3}{*}{7.} & Mual & & \\
\hline & Tidak & 30 & 96,8 \\
\hline & Ya & 1 & 3,2 \\
\hline \multirow[t]{3}{*}{8.} & Muntah & & \\
\hline & Tidak & 30 & 96,8 \\
\hline & Ya & 1 & 3,2 \\
\hline \multirow[t]{3}{*}{9.} & Diare & & \\
\hline & Tidak & 30 & 96,8 \\
\hline & Ya & 1 & 3,2 \\
\hline \multirow[t]{3}{*}{10.} & Pilek & & \\
\hline & Tidak & 30 & 96,8 \\
\hline & Ya & 1 & 3,2 \\
\hline \multirow[t]{2}{*}{11.} & Ruam kulit & & \\
\hline & Tidak & 31 & 100 \\
\hline \multirow[t]{2}{*}{12.} & Konjungtivitis & & \\
\hline & Tidak & 31 & 100 \\
\hline \multirow[t]{3}{*}{13.} & Nafsu makan berkurang & & \\
\hline & Tidak & 30 & 96,8 \\
\hline & Ya & 1 & 3,2 \\
\hline
\end{tabular}

\section{PEMBAHASAN}

Murni Teguh Memorial Hospital membuka layanan perawatan COVID-19 sejak bulan Maret 2020. Tenaga kesehatan khususnya perawat memiliki resiko terpapar
COVID-19 karena perawat berada di garis terdepan dalam menghadapi COVID-19, sehingga sangat rentan mengalami sakit ataupun meninggal (ICN, 2020). Murni Teguh Memorial Hospital memfasilitasi perawat untuk berobat segera apabila mengalami sakit atau memiliki keluhan kesehatan, terkhusus pada perawat yang pernah kontak dengan pasien yang diduga terinfeksi COVID-19.

Penelitian ini menghasilkan gambaran gejala COVID-19 pada perawat bervariasi, mulai dari keadaan asimptomatik, gangguan gastrointestinal hingga gangguan pernafasan. Mayoritas perawat yang terkonfirmasi positif COVID-19 merasakan gejala seperti hilangnya indera penciuman, demam, dan batuk. Penelitian Karni et al. (2020) menunjukkan bahwa perubahan indera penciuman pada pasien COVID-19 terjadi hampir sepuluh kali lebih tinggi di bandingkan pada orang yang negatif COVID19. Penelitian Gerkin et al. (2020) memaparkan bahwa kehilangan kemampuan indera penciuman merupakan prediktor terbaik dari COVID-19. Gejala Hilangnya indera penciuman lebih prediktif daripada gejala utama lainnya seperti demam ataupun batuk. Pemulihan indera penciuman terjadi dalam 40 hari sejak timbulnya onset penyakit.

Penelitian Guan et al. (2020) yang dilakukan di China menunjukkan bahwa gejala yang umumnya terjadi pada pasien COVID-19, yaitu demam (88,7\%). Kemudian, gejala kedua yang paling umum adalah batuk $(67,8 \%)$. Untuk mual dan muntah sebesar $5 \%$, dan diare jarang terjadi $(3,8 \%)$.

Penelitian Huang et al. (2020) juga menunjukkan bahwa gejala COVID-19 yang paling umum adalah demam, batuk, mialgia atau kelelahan dan sesak nafas. Gejala lain yang jarang terjadi, yaitu sakit kepala dan diare. Sementara itu, penelitian $\mathrm{Xu}$ et al. (2020) di Provinsi Zhejiang China menunjukkan bahwa gejala yang paling umum adalah demam (77\%), batuk (81\%), batuk berdahak $(56 \%)$, sakit kepala $(34 \%)$, mialgia atau kelelahan $(52 \%)$, diare $(8 \%)$, 
dan hemoptisis (3\%). Hanya dua pasien (3\%) yang mengalami sesak napas saat masuk rumah sakit.

Hingga saat ini, belum ada obat atau vaksin yang dikonfirmasi untuk mengobati penyakit ini, sehingga tenaga kesehatan khususnya perawat dan juga seluruh masyarakat penting untuk mewaspadai ataupun mencegah penyebaran COVID-19. Strategi pencegahan yang penting untuk dilakukan adalah mematuhi protokol kesehatan yang telah di tetapkan oleh pemerintah seperti melakukan kebersihan tangan, menjaga jarak, menghindari kerumunan dan patuh dalam menggunakan Alat Pelindung Diri (masker, face shield dan lainnya).

\section{KESIMPULAN}

Penelitian ini bertujuan untuk mengetahui gejala COVID-19 yang dialami perawat yang terkonfirmasi COVID-19. Gejala yang dialami perawat bervariasi, mulai dari keadaan asimptomatik hingga gangguan pernafasan. Namun, gejala dominan yang dirasakan oleh perawat, yaitu hilangnya kemampuan indera penciuman, demam, dan batuk.

\section{SARAN}

Peneliti merekomendasikan bagi penelitian selanjutnya melakukan penelitian mengenai COVID-19 dari sisi psikologis.

\section{REFERENSI}

CNN. (2020). Kilas Balik Pandemi Covid-19 di Indonesia. Diakses dari https://m.cnnindonesia.com

Gerkin, et al. (2020). The best COVID-19 predictor is recent smell loss: a crosssectional study. medRxiv: The Preprint Server for Health Sciences. https://doi.org/10.1101/2020.07.22.2 0157263

Huang, et al. (2020). Clinical features of patients infected with 2019 novel coronavirus in Wuhan, China. Lancet. https://doi.org/10.1016/S01 40-6736(20)30183-5
International Council of Nurses. (2020). COVID-19 and the International Supply of Nurses. Diakses dari https://www.icn.ch

Karni, N et al (2020). Self-rated smell ability enables highly specific predictors of COVID-19 status: a case control study in Israel. medRxiv: The Preprint Server for Health Sciences. https://doi.org/10.1101/2020.07.30.2 0164327

Kementerian Kesehatan Republik Indonesia. (2020). Dashboard Data Kasus COVID-19 di Indonesia. Diakses dari kemkes.go.id

Singhal, T. (2020). A review of coronavirus disease-2019 (COVID-19). The Indian Journal Pediatrics, 87 (4), 281-286. https://doi.org/10.1007/s12 098-020-03263-6

World Health Organization. (2020). WHO Coronavirus Disease (COVID-19) Dashboard. Diakses dari covid19. who.int

$\mathrm{Xu}$, et al. (2020). Clinical findings in a group of patients infected with the 2019 novel coronavirus (SARS-Cov-2) outside of Wuhan, China: retrospective case series. BMJ. doi: 10.1136/bmj.m606 